\section{Failed vaccine campaigns may lead to polio resurgence, experts warn}

John Zaracostas Geneva

Experts have said that the failure by the four remaining countries where polio is endemic to wipe out the disease could cause a resurgence of more than 250000 cases a year. Polio remains endemic in Nigeria, India, Pakistan, and Afghanistan.

"It would be a humanitarian catastrophe not to complete polio eradication now that we are so close ... to the finish line," said Robert Scott, chairman of Rotary International's "PolioPlus" committee.

"Polio eradication hinges on vaccine supply, community acceptance, funding, and political will. The first three are in place. The last will make the difference," he said.

However, to prevent the international spread of polio the experts have also recommended that future World Health Organization travel documents concerning personal protection for travellers stress the importance of immunisation of people going to areas with polio, said David Heymann, WHO's special envoy for polio eradication.

Countries without polio have been taking measures to protect themselves from importation of the virus. Saudi Arabia has until the second half of 2004

This pause was largely responsible for 25 countries becoming reinfected in Africa, Asia, and the Middle East through importations of the virus.

Peter Ndumbe, director of the

enforced stringent polio immunisation requirements for the upcoming pilgrimage to Mecca.

From 1 January to 10 October 2006 the number of confirmed polio cases worldwide stood at 1403 (the number for the same period in 2005 was 1349), of which 888 were in Nigeria (up from 489 in the same period last year), 360 in India (37 last year), 24 in Pakistan (18 last year), and 28 in Afghanistan (four last year)

In 2005 the total number of polio cases was 1973, considerably less than the 350000 cases a year in the 1980 s.

The global eradication initiative was launched in 1988 and spearheaded by WHO, Unicef, the US Centers for Disease Control and Prevention, Rotary International, and national governments. However, the initiative failed to meet the target date of the end of 2005 for eradicating the virus.

In late 2003 religious and community leaders in the mostly Muslim state of Kano, in northern Nigeria, spread unfounded rumours that polio immunisation was an attempt to sterilise women, bringing the immunisation campaign there to a halt
Dr Cochi, who is also acting director of the national immunisation programme at the US Centers for Disease Control, said that "the political leaders in the remaining few districts and states where polio continues cannot be allowed to shirk their responsibilities."

The quality of the polio campaigns in northern Nigeria is not considered good enough. It is thought that as many as half of children in some infected areas there have never been immunised, the committee notes.

Also, immunisation campaigns are not reaching all children in Pakistan and Afghanistan (where coverage ranges from $75 \%$ to $90 \%$ ) and in parts of India, such as Uttar Pradesh and Bihar, where polio is endemic.

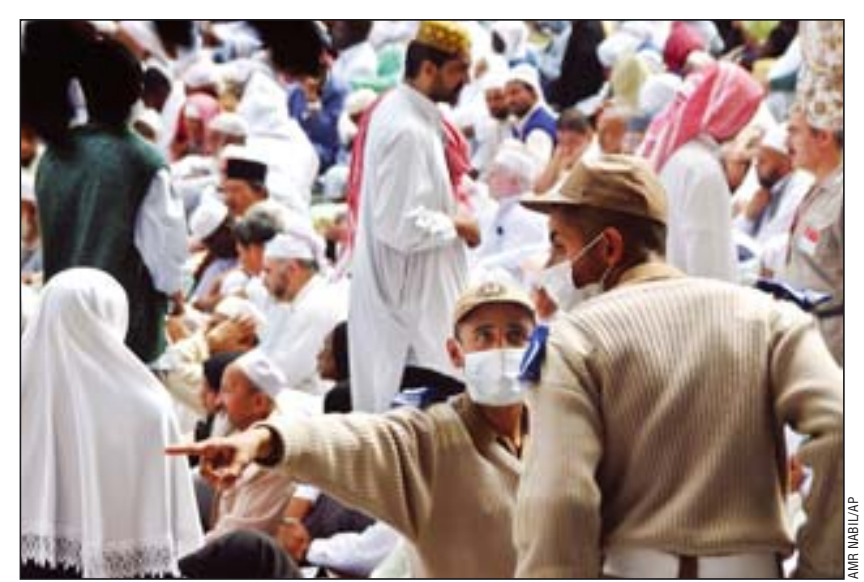

Saudi Arabia has issued tight polio immunisation requirements for pilgrims at the Great Mosque, Mecca

\section{Israeli doctors are arrested in investigation}

Judy Siegel-Itzkovich Jerusalem

Four doctors at the Kaplan Medical Centre-Harzfeld Geriatric Hospital south of Tel Aviv were arrested and brought before the Tel Aviv magistrates' court on Monday 9 October. The arrests were made as part of an ongoing investigation by the national fraud squad into alleged illegal medical experiments they conducted between 2000 and 2003 on elderly patients, some of whom were in their $90 \mathrm{~s}$ and had dementia.

Three of the four doctors have been named. They are Shmuel Levi, former director of Harzfeld Hospital and former deputy director of Kaplan Hospital in Rehovot under whose aegis Harzfeld operates; Alona Smirnov, formerly a junior doctor at Harzfeld; and Nadia Kagansky, who is still a senior doctor and director of a department at Harzfeld. The three named doctors were under house arrest until 19 October.

Detectives searched the suspects' homes and seized numerous documents relating to the investigation, which was launched after the police received a complaint from the health ministry.

The ministry looked into the matter in May 2005 after Israel's then state comptroller, the retired supreme court justice Eliezer Goldberg, published a chapter in his six monthly report that lambasted ministry officials for negligence in supervising medical experimentation ( $B M$ J 2005;330:1170).
The state comptroller also criticised the ministry for taking eight years to produce a government bill for regulation of clinical trials, which only now is in the final stages of preparation and due to be presented before the Knesset (parliament) in its autumn session.

Shlomo Breznitz, a Knesset member and clinical psychologist, recently tabled his own bill to establish ongoing supervision of doctors after permission is granted under the terms of the 1964 Declaration of Helsinki concerning informed consent. The system, he said, must be changed, because once permission is granted researchers may do as they wish. "I know the loopholes," he said. "This very complicated and comprehensive bill would fix many of the current problems with human experiments."
The Israel Medical Association recently called for major legislation to regulate clinical research and to require all medical students and researchers to undergo courses in good clinical practice. The chairman of the association's ethics bureau, Avinoam Reches, said that although there is a law regulating animal experimentation, no equivalent law exists governing clinical trials, only a hotchpotch of state regulations.

Zev Rothstein, director of Israel's largest hospital, the Sheba Medical Centre near Tel Aviv, said that inefficiency in the ministry's approval process forced Israeli biotechnology companies to "export" their research to Europe and the United States and discouraged international drug companies from commissioning research from Israel's best researchers. $\square$ 